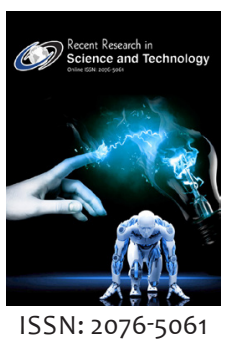

Received: December 05, 2019 Accepted: December 27, 2019 Published: December 29, 2019

*Corresponding Author: M. Cüneyt Bağdatlı Email: cuneytbagdatli@ gmail.com

\section{Evaluation of the number of rainy days observed for long years due to global climate change in Nevşehir/Turkey}

\author{
M. Cüneyt Bağdatlı ${ }^{\text {** }}$ Oğuzhan Arslan² \\ ${ }^{1}$ Nevsehir Hacı Bektas Veli University, Engineering and Architecture Faculty, Department of Biosystem Engineering, \\ Nevsehir / Turkey, ${ }^{2}$ Nevsehir Hacı Bektas Veli University, Institute of Science, Department of Environmental \\ Engineering, Nevsehir / Turkey
}

\begin{abstract}
In this research caried out Nevsehir province, Avanos and Ürgüp districts of Turkey's Central Anatolia Nevsehir. In the study, it is aimed to reveal the trends of years by changing the number of long year total rainy days by Mann Kendall and Sperman's Rho correlation tests. Within the scope of the study, 34 years long total monthly rainy days data between 1986-2019, which were obtained from automatic meteorology stations, were evaluated. According to the results of the trend analysis, the average total number of rainy days in Nevşehir province was 77 days minimum, the maximum number of rainy days was 142 days, and the average of the average number of rainy days was 109 days. In Avanos district, the average number of rainy days for a long time was 57 days, and the maximum number of rainy days was 129 days, while the average of the number of rainy days for long years was 89 days. In Ürgüp district, the average number of rainy days for a long time was 65 days, the maximum number of rainy days was 129 days, and the average of the number of rainy days for long years was 95 days. As a result, considering the number of long year rainy days, it is concluded that there is no significant trend in Nevşehir province, Avanos and Ürgüp district stations.
\end{abstract}

KEYWORDS: Number of rainy days, global climate change, Nevsehir province, Turkey

\section{INTRODUCTION}

The decrease in precipitation due to the increase in temperature in the world will lead to decrease in water resources and accordingly, the problems of global water crisis. As a natural result of the widespread interest in increased greenhouse effect and possible effects of global warming, a number of studies have been conducted to identify the changes and trends observed in long-term temperature and precipitation data $[1,2,3,4]$.

It requires water, which is one of the basic needs, for people and living creatures to survive. The biggest source of water is precipitation. Rainfall is a factor in many events on Earth. Agricultural production, living life, migration and urbanization etc. events take place mainly. Although low precipitation causes many factors, global climate will occur due to negative factors that will occur due to change. These decreases observed in precipitation in parallel with the increasing tendency of temperature will cause larger problems related to water resources [5]. This research was carried out to examine the 34 years total number of rainy days on a seasonal basis and to reveal the trend in the long period, observed between 1986-2019, obtained from the meteorological stations in the districts of Nevşehir Province, Avanos and Ürgüp Districts.

\section{MATERIAL AND METHOD}

The study area is located in Turkey's Central Anatolia in Nevsehir province, Avanos and Urgup district covers. In the study, the number of long-term monthly rainy days between 1986 and 2019 belonging to the Nevşehir Province Avanos, Ürgüp districts's meteorology stations was used as the study material. The location and location of Avanos and Ürgüp districts of Nevşehir province, which are the subject of the study, can be seen on the map given in Figure 1.

In the study, monthly changes in the number of rainy days observed in the Nevşehir province, Avanos and Ürgüp meteorology stations between 1986-2019 were used. It was analyzed for 408 months in total and the values obtained were statistically based on graphs and charts. In this sense, in order to evaluate the data, it was evaluated within the scope of Rho Kendall Test of Mann Kendall and Sperman's Trend methods were performed in $95 \%$ confidence level $[6,7]$. In

Copyright: ๑ The authors. This article is open access and licensed under the terms of the Creative Commons Attribution License (http://creativecommons.org/licenses/by/4.0/) which permits unrestricted, use, distribution and reproduction in any medium, or format for any purpose, even commercially provided the work is properly cited. Attribution - You must give appropriate credit, provide a link to the license, and indicate if changes were made. 
the study, a software called "Trend Analysis for Windows", Mann-Kendall test, Spearman's Rho test, Mann-Kendall order Correlation test and Sen's Trend Slope method are applied to the data and the result is given as graphics and text. [8].

\section{RESEARCH FINDINGS}

The trend analysis results of the total number of rainy days between 1986 and 2019 for the Nevsehir city center, Avanos and Ürgüp districts's meteorology stations are presented in detail below. Nevşehir province, Avanos and Ürgüp districts, which were analyzed for many years (1986-2019), were evaluated seasonally (spring, autumn, summer and winter months) with trend analysis. The trend of Nevşehir Center for long annual and seasonal total number of rainy days is given in Figure 2. Avanos district trend analysis results are shown in detail in Figure 3 and Ürgüp district trend analysis results are given in detail in Figure 3.

It is known that the total precipitation values for many years in the city center of Nevşehir are $123.5 \mathrm{~mm}$ in winter, and the average maximum precipitation values in winter are $11.2 \mathrm{~mm}$. Considering the number of rainy days, the lowest number of rainy days in winter was 22 days in 1999, while the highest number of rainy days was 55 days in 2008.

It is known that the total precipitation values are $130.3 \mathrm{~mm}$ in the spring months and the average rainfall values are $13.6 \mathrm{~mm}$ in average. The lowest number of rainy days is 26 days in 2009, while the highest number of rainy days was 59 days in 2011.

While the lowest number of rainy days in the summer was 2 days in 2013, the highest number of rainy days was observed in 24 days in 1999. Total rainfall values are known as $37.5 \mathrm{~mm}$ in the summer months, and the average maximum precipitation values are known to be $7.5 \mathrm{~mm}$ in the summer months.

It is known that the total precipitation values are $71.6 \mathrm{~mm}$ in the autumn months and the average precipitation value is $11.5 \mathrm{~mm}$. While the lowest number of rainy days in autumn was 8 days in 2019, the highest number of rainy days was 33 days in 1988.

It is known that in the long years (1986-2019) total precipitation values are $362.9 \mathrm{~mm}$ and average maximum precipitation values are $10.9 \mathrm{~mm}$. On the basis of many years, the lowest number of rainy days was 77 days in 2013, while the highest number of rainy days was 142 days in 2018. Long-term (1986-2019) and seasonal trend analysis results of Nevşehir Center for many years total rainy days values are given in Table 1 .

According to the results of the trend analysis made for the total number of rainy days on the basis of many years, it was concluded that according to the Rho Tests of Mann-Kendall and Sperman, there is no trend on the basis of winter, spring and summer seasons, and there is a decreasing trend in the autumn season. The graphs of Avanos District Long Years

Table 1: Total number of rainy days trend analysis results for many years in Nevsehir province

\begin{tabular}{|c|c|c|c|c|}
\hline Provinces & Years & Seasons & Mann-Kendall Testi & Spearman'in Rho Testi \\
\hline \multirow{5}{*}{ 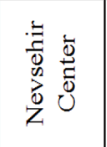 } & \multirow{5}{*}{$\begin{array}{l}0 \\
0 \\
0 \\
0 \\
\infty \\
0 \\
-\end{array}$} & Spring Months & 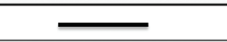 & $\longrightarrow$ \\
\hline & & Summer Months & $\longrightarrow$ & \\
\hline & & Autumn Months & $-\sqrt{1}$ & $-\sqrt{2}$ \\
\hline & & Winter Months & & \\
\hline & & General Average & & \\
\hline
\end{tabular}

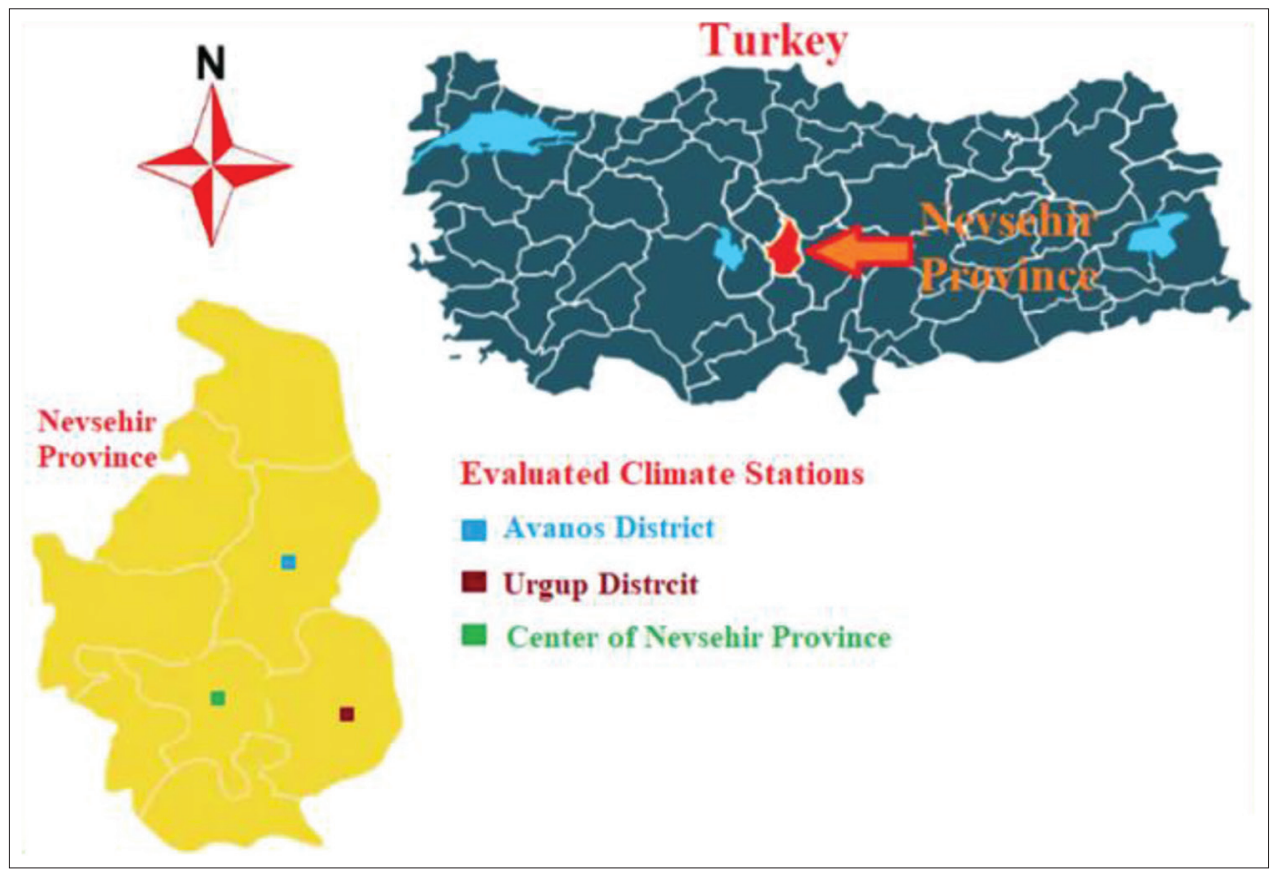

Figure 1: Positions and boundaries of the study areas 


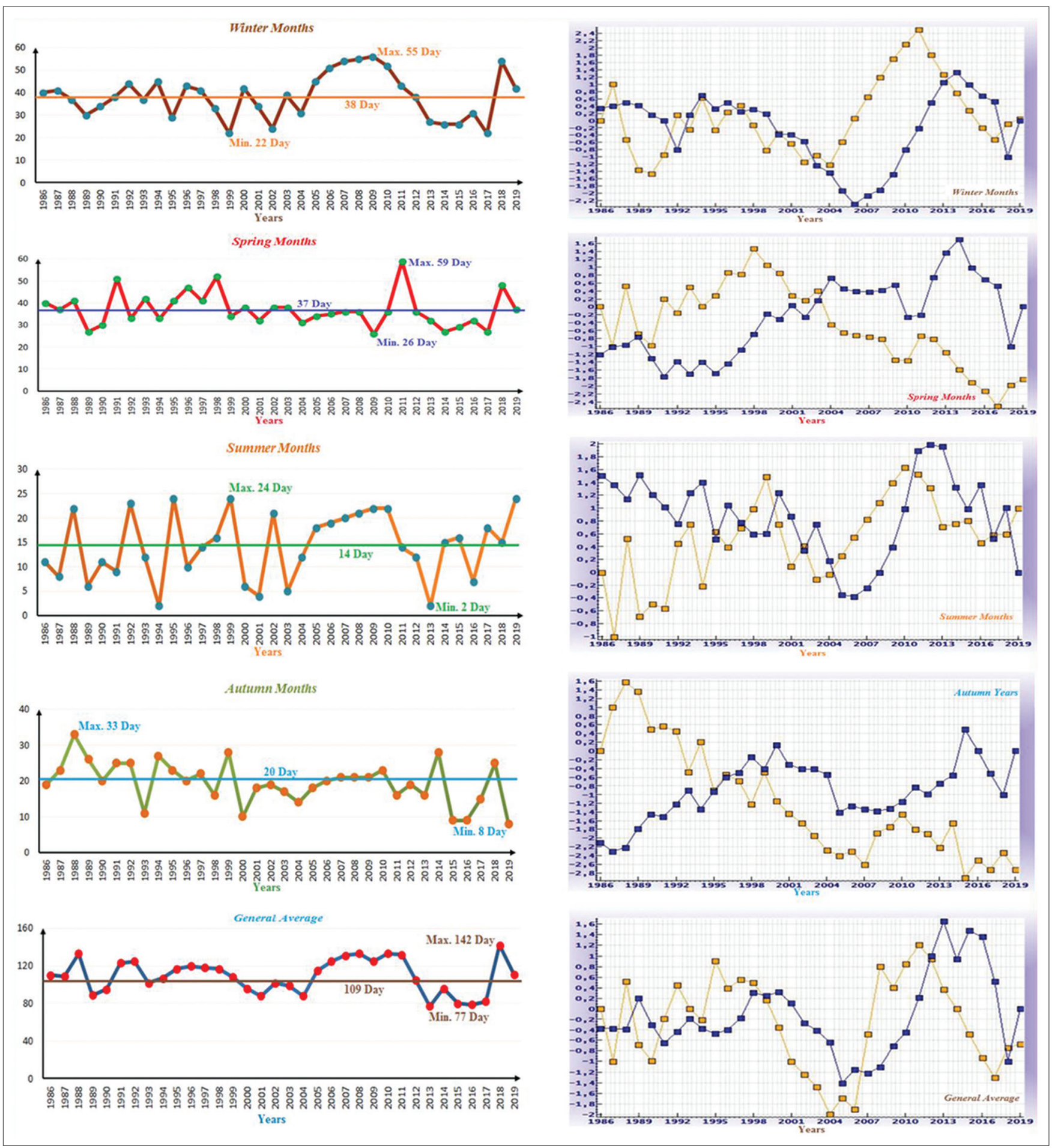

Figure 2: Seasonal change trends in the total number of rainy days observed in Nevşehir province

Total Number of Rainy Days, Seasonal and Years Changes are given in Figure 3.

It is known that the total precipitation values of Nevşehir province Avanos district for many years are $196.1 \mathrm{~mm}$ in winter, and the average maximum precipitation value in winter is $10.5 \mathrm{~mm}$. Considering the number of rainy days, the lowest number of rainy days in winter was 13 days in 1989, while the highest number of rainy days was 49 days in 2018.
It is known that the total precipitation values are $102.6 \mathrm{~mm}$ in the spring months and the average precipitation values are $11 \mathrm{~mm}$. The lowest number of rainy days was 2 days in 1995 , while the highest number of rainy days was 52 days in 2011 .

While the lowest number of rainy days in summer was 4 days in 2013, the highest number of rainy days was 21 days in 2019. It is known that the total precipitation values are $32 \mathrm{~mm}$ in the summer months and the average precipitation value is $7.4 \mathrm{~mm}$. 


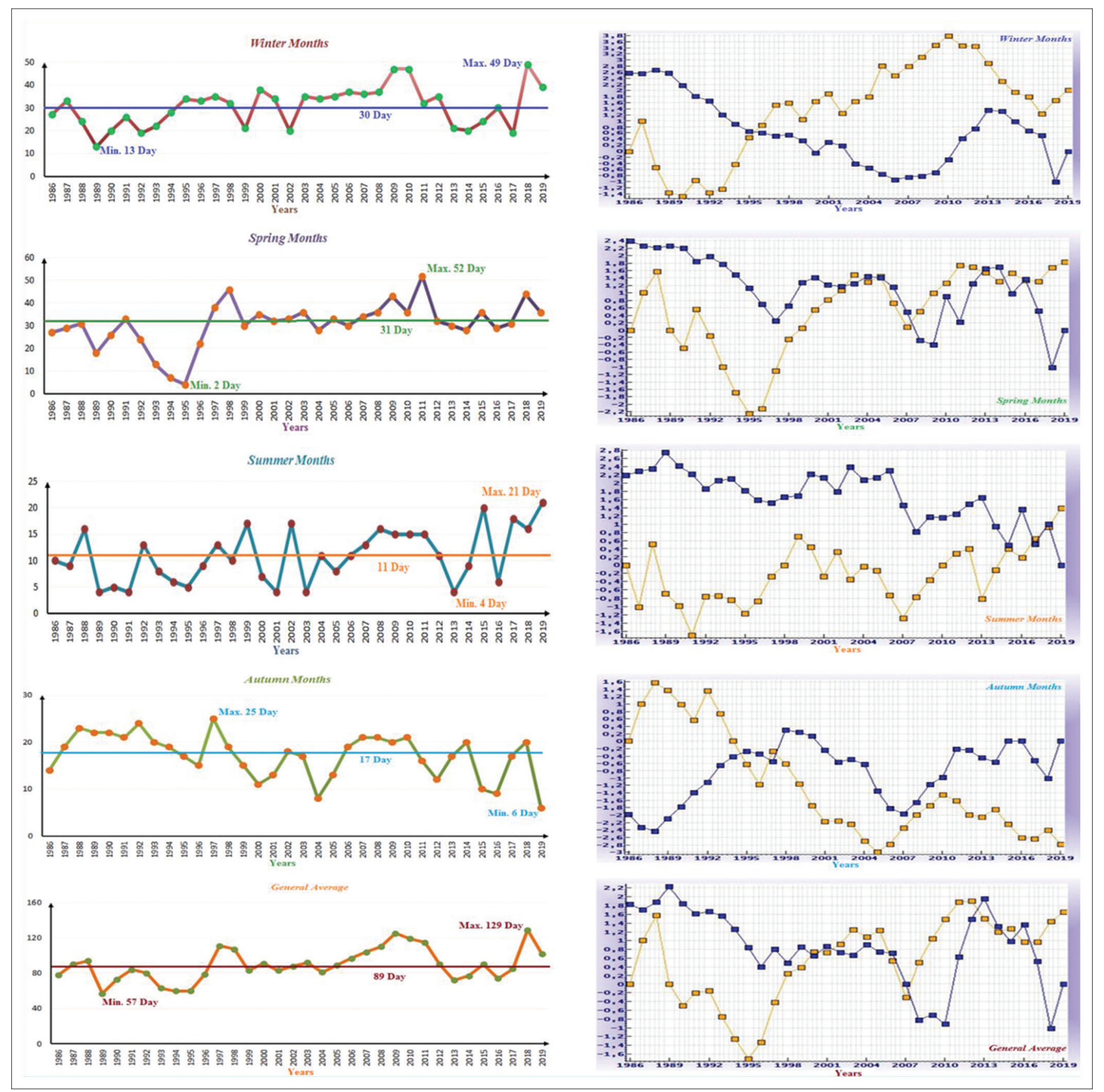

Figure 3: Seasonal change trends in the total number of rainy days observed in Avanos district

It is known that the total precipitation values are $62.1 \mathrm{~mm}$ in the autumn months and the average precipitation values are $9 \mathrm{~mm}$. While the lowest number of rainy days in autumn was 6 days in 2019, the highest number of rainy days was 25 days in 1997.

It is known that in the long years (1986-2019), the total precipitation values are $292.8 \mathrm{~mm}$ and the average maximum precipitation values are $9.5 \mathrm{~mm}$. On the basis of many years, the lowest number of rainy days was 57 days in 1989, while the highest number of rainy days was 129 days in 2018. Long-term (1986-2019) and seasonal trend analysis results of the total number of rainy days in Nevşehir Center are given in Table 2.
Table 2: Long years total number of rainy days trend analysis results in Avanos district

\begin{tabular}{|c|c|c|c|c|}
\hline Provinces & Years & Seasons & Mann-Kendall Testi & Spearman'in Rho Testi \\
\hline \multirow{5}{*}{ 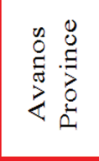 } & \multirow{5}{*}{$\begin{array}{l} \\
0 \\
0 \\
0 \\
1 \\
0 \\
0 \\
0 \\
0\end{array}$} & Spring Months & & $\bar{C}$ \\
\hline & & Summer Months & +1 & \\
\hline & & Autumn Months & & $-\sqrt{2}$ \\
\hline & & Winter Months & +1 & +1 \\
\hline & & General Average & & \\
\hline
\end{tabular}

According to the results of the trend analysis on the total number of rainy days on the basis of many years, according to the Rho-Tests of Mann-Kendall and Sperman, there is no trend

Recent Res Sci Technol $\quad$ - 2019 • Vol 11 
on the basis of spring and autumn seasons, there is an increasing trend in the winter season, according to the Mann-Kendall plant in the summer season. It was concluded that there was an increasing trend and in the autumn season there was a decreasing trend according to Sperman's Rho test. The graphs of Ürgüp District Long Years Total Number of Rainy Days, Seasonal and Years Changes are given in Figure 4.

It is known that the total rainfall values of Nevşehir province, Ürgüp district are $96.2 \mathrm{~mm}$ in winter, and the average maximum precipitation value in winter is $11.2 \mathrm{~mm}$. Considering the number of rainy days, the lowest number of rainy days in winter was 16 days in 1989, while the highest number of rainy days was 50 days in 2009.

It is known that the total precipitation values are $123.4 \mathrm{~mm}$ in the spring months and the average precipitation values are $13.6 \mathrm{~mm}$. The lowest number of rainy days was 19 days in 1989, while the highest number of rainy days was 52 days in 2011 .

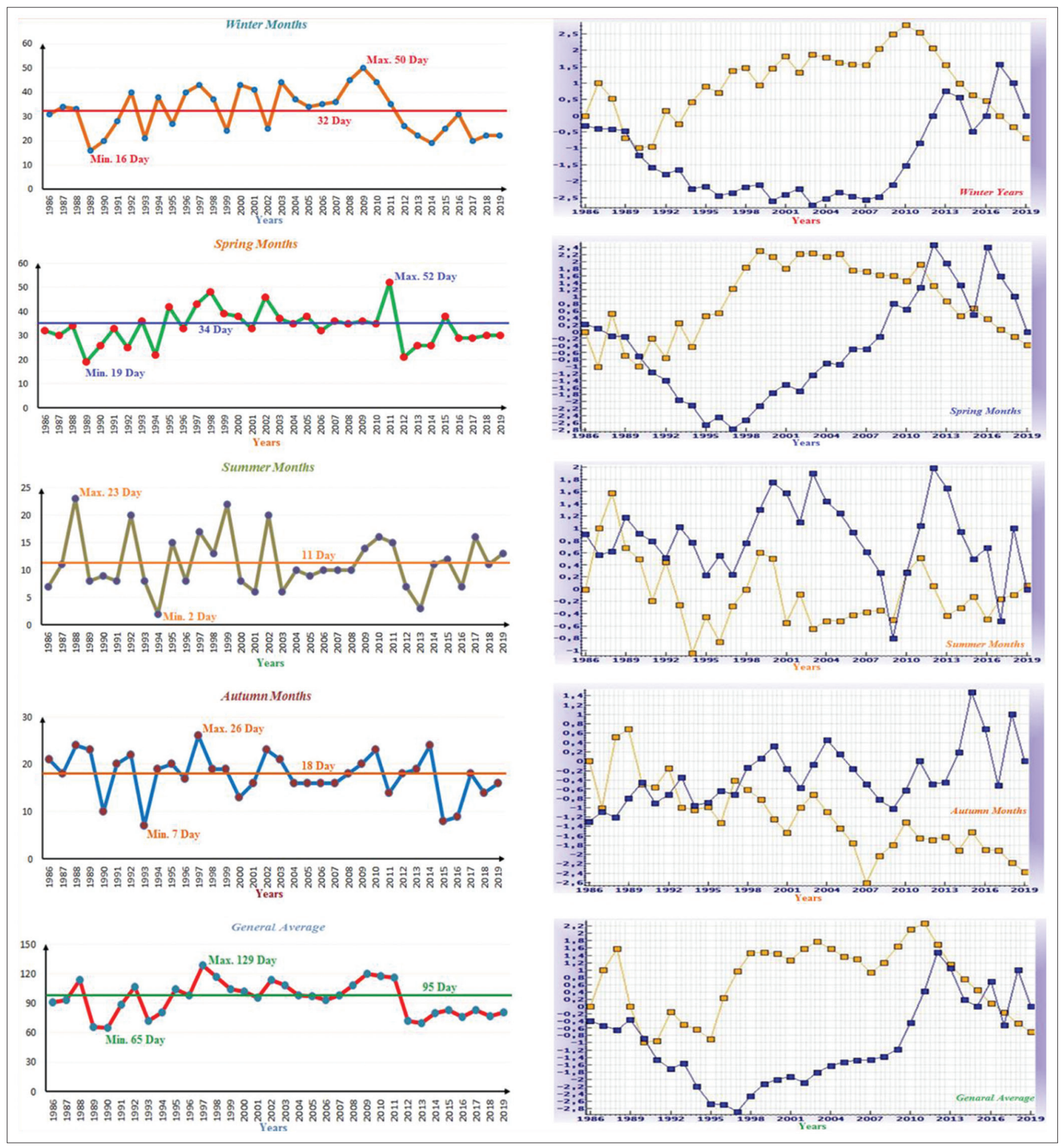

Figure 4: Seasonal Change Trends in the total number of rainy days observed in Ürgüp district 
Table 3: The number of rainy days for many years trend analysis results in Ürgüp district

\begin{tabular}{|c|c|c|c|c|}
\hline Provinces & Years & Seasons & Mann-Kendall Testi & Spearman'in Rho Testi \\
\hline \multirow{5}{*}{ 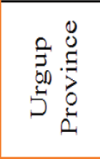 } & \multirow{5}{*}{$\begin{array}{l}0 \\
0 \\
0 \\
1 \\
0 \\
\infty \\
0 \\
-\end{array}$} & Spring Months & & \\
\hline & & Summer Months & & \\
\hline & & Autumn Months & - & $-\nabla$ \\
\hline & & Winter Months & & \\
\hline & & General Average & & \\
\hline
\end{tabular}

While the lowest number of rainy days in summer was 2 days in 1994, the highest number of rainy days was 24 days in 1988. It is known that the total precipitation values are $32.3 \mathrm{~mm}$ in the summer months and the average precipitation value is $7.5 \mathrm{~mm}$.

It is known that the total precipitation values are $76.5 \mathrm{~mm}$ in the autumn months and the average precipitation value is $11.6 \mathrm{~mm}$. While the lowest number of rainy days in autumn was 7 days in 1993, the highest number of rainy days was 26 days in 1997.

It is known that in the long years (1986-2019) total precipitation values are $328.3 \mathrm{~mm}$, average maximum precipitation values are $10.9 \mathrm{~mm}$. On the basis of many years, the lowest number of rainy days was 65 days in 1990, while the highest number of rainy days was 129 days in 1997. Long-term (1986-2019) and seasonal trend analysis results of Nevşehir Center for many years total rainy days values are given in Table 3 .

According to the results of the trend analysis conducted on the total number of rainy days on the basis of many years, the general average according to the Rho-Tests of Mann-Kendall and Sperman is not trending on the basis of winter, spring, summer and autumn seasons, and in the decreasing direction compared to Sperman's Rho test in the autumn season. concluded that there is a trend.

\section{CONCLUSION AND SUGGESTIONS}

In this study, where the total number of rainy days per month on the basis of long years (1986-2019) was 34 years and 408 months in total, there was a seasonal change in the number of rainy days and especially in the recent years due to global warming, a decrease in the spring and autumn season values It was observed. Considering the monthly total rainy days, the long-term total values of Nevşehir Central station are 38 days for the winter months, 37 days for the spring months, 14 days for the summer months, 27 days for the autumn months, and the general average is 109 days. Nevşehir province Avanos district station has been observed as 30 days for winter months, 31 days for spring months, 11 days for summer months, 17 days for autumn months, and overall average is 89 days.

Nevşehir province Ürgüp district station has been observed as 32 days for winter months, 34 days for spring months, 11 days for summer months, 18 days for autumn months, and overall average is 95 days. As a result of the trend analysis, a decreasing trend was observed in autumn and an upward trend in winter. In this study, which was carried out within the scope of evaluating the total number of monthly rainy days in the district of Nevşehir, Centrum, Avanos and Ürgüp due to the global climate change, it was concluded that the total number of rainy days per month decreased in the seasons when precipitation is frequent. The fact that precipitation, which is of vital importance for living creatures around the world, tends to decrease especially in the seasons when rain is frequent will cause water resources to decrease. Along with this, the problems of living life falling, decreasing productivity in agricultural production and being negatively affected in some industrial companies. Increasing the impact of global climate change will be a faster source of these negative stages and the main source of global water crisis problems between countries. In order to reduce this global climate change effect, reducing the necessary measures and measures before it will be an important factor.

\section{REFERENCES}

1. Türkeş M. Spatial and temporal analysis of annual rainfall variations in Turkey". Int J Climatology, 1996: 16:1057-1076.

2. Türkeş M, Sümer.M, Kılıç G. "Observed changes in maximum and minimum temperatures in Turkey". International Journal of Climatology, 1996: 16: 463-477.

3. Kadıoğlu M. Trends in surface air temperature data over Turkey". International Journal of Climatology 1997: 17: 511-520.

4. Tayanç M, Karaca M, Yenigün O. Annual and seasonal air temperature trend patterns of climate change and urbanization effects in relation to air pollutants in Turkey". Journal of Geophysical Research 1997: 102 : 1909- 1919.

5. Türkeş M. Vulnerability of Turkey to Desertification with Respect to Precipitation Andridity Conditıon, Ankara, 1999.

6. Mann HB, Non-parametric Tests Against Trend. Econometrica, 1945: (13)245-259.

7. Kendall M G. Rank Correlation Methods. Charles Griffin, London, 1975:135.

8. Gümüş V, Yenigün K. Fırat Havzası Akımlarının Trend Analizi İle Değerlendirilmesi, Harran Üniversitesi Fen Bilimleri Enstitüsü İnşaat Mühendisliği AnabilimDalı Yüksek Lisans Tezi, 2006, Şanlıurfa (in turkish). 